\title{
Attitudes And Preferences of Wildlife And Their Relationship With Childhood Nature Experience Amongst Residents In A Tropical Urban City
}

Kang Min Ngo ( $\sim$ ngokangmin@gmail.com )

Tokyo Metropolitan University: Shuto Daigaku Tokyo https://orcid.org/0000-0001-8273-6158

Tetsuro Hosaka

Tokyo Metropolitan University: Shuto Daigaku Tokyo

Shinya Numata

Tokyo Metropolitan University: Shuto Daigaku Tokyo

\section{Research Article}

Keywords: coexistence, habitat preference, Singapore, urban wildlife

Posted Date: June 17th, 2021

DOl: https://doi.org/10.21203/rs.3.rs-287832/v1

License: (c) This work is licensed under a Creative Commons Attribution 4.0 International License. Read Full License 


\section{Abstract}

How people relate to biodiversity and whether they are supportive of conservation programs and policies has implications on global and local biodiversity conservation efforts. Nature experiences in childhood has been shown to be strongly correlated to positive attitudes towards nature and wildlife in adulthood. In this study, we examined wildlife experience, attitudes and willingness to coexist with 26 vertebrates and invertebrates amongst residents in a highly urbanized tropical city, Singapore. A total of 1004 respondents were surveyed and their childhood nature experience and various socioeconomic variables were obtained. The animals were grouped by their likeability and preferred habitat from the respondents' answers. Three main groups of animals were discerned - unfavorable animals, mammals, and favorable animals. Singapore residents generally had high direct experiences of animals that are common in urban settings, for both favorable and unfavorable animals, such as butterflies, dragonflies, crows and bees, but low direct experiences of forest-dependent wildlife. Animals that were well-liked and acceptable near homes include the common urban ones and some forest-dependent ones, while animals that were disliked included stinging insects (bees and hornets) and reptiles (snakes and water monitors). The apparent mismatch between greening policies and people's willingness to coexist with wildlife may be problematic as urban development further encroaches on forest habitats, and this study highlights the importance of preserving forest habitats so that young children and adults have opportunities to be exposed to them.

\section{Introduction}

As cities worldwide move towards greening and sustainability, more green areas are set aside for public welfare and social needs (Anguelovski et al. 2018). With increasing green spaces and wildlife reserves in numerous cities (Anguelovski et al. 2018; Jim and Chen 2003; Li et al. 2005), urban wildlife is expected to increase in abundance and diversity, including both 'desirable' and pest or undesirable species. Peoples' feelings and attitudes towards wildlife affects their willingness to coexist with them, and may contribute to or deter larger biodiversity conservation goals (Castillo-Huitrón et al. 2020; Frank 2016).

The need for biodiversity conservation has not been more urgent. Worldwide, biodiversity has been greatly reduced in the past five decades due to habitat losses and degradation (Butchart et al. 2010), and this reduction is continuing in the face of climate change (Trisos et al. 2020). Changes in biodiversity can have negative impacts on ecosystems (Cardinale et al. 2012), human health, food production, and water supply, with high monetary costs (Chapin et al. 2000). These changes affect ecosystem processes, leading to further changes in species composition and vulnerability to invasion by exotic species (Chapin et al. 2000).

Cities can be places for biodiversity conservation with proper planning (Aronson et al. 2017; Kowarik 2011), but more importantly they are important places to teach and spread the idea of biodiversity conservation, and why it matters to humans. 
The willingness to coexist with wildlife is an important step towards a meaningful and effective urban greening plan. If cities are aiming to be greener, and if being greener means attracting a greater diversity and abundance of wildlife (Strohbach et al. 2013), then residents need to learn and accept that outdoor green space do not belong to humans alone, but a space to be shared with a variety of plants and animals, even if they are not affectively favored (Crespin and Simonetti 2019).

Children's contact with nature has been shown to affect their willingness to conserve biodiversity (Zhang et al. 2014, Soga et al. 2016b), and these attitudes are very likely to be carried on to adult life in the form of environmental activism (Hsu 2009; Li and Chen 2015). Formative experiences in nature and conservation issues are not necessarily restricted to the childhood period too (Reibelt et al. 2017). These studies suggest that positive nature experiences in childhood are significantly associated with caring action for the environment in adulthood, and demonstrate the necessity of first-hand experience and discoveries in fostering environmental action (Chawla and Derr 2012).

In Singapore, a highly urbanized island city, human-wildlife interactions are very common. Several studies have been done on human-macaque (Long-tailed Macaque, Macaca fascicularis) conflicts in Singapore (Sha et al. 2009; Yeo and Neo 2010), because they were amongst the first mammal species to be considered problematic since the 1990s. These conflicts were attributed to human-induced causes (Sha et al. 2009), but government-led culling of the macaques nevertheless occurred when complaints increased (Feng 2013). Since then, other animals are being increasingly perceived as problematic too, such as the wild boar (Sus scrofa; Goh and Toh 2018) and the reticulated python (Malayopython reticulatus, Tan 2019).

Negative perceptions and fear of wildlife have been attributed to a lack of exposure and knowledge about them. This is especially true for urban residents, since their likelihood of growing up in more natural environments is lower (Mohamad Muslim et al. 2017). Low childhood nature experience was found to be strongly correlated to negative attitudes and low tolerance for problem-causing wildlife amongst urban residents in Singapore (Ngo et al. 2019). The desired treatment of these wildlife also depended on the taxa - more people preferred the extermination of invertebrates near their homes if these animals were known to have caused serious injury, compared to macaques ( $\mathrm{Ngo}$ et al. 2019). Complaints and requests for removals were also made if wildlife were sighted at urban infrastructure away from nature areas, such as within drainage canals, even if the wildlife has not done any damage (Liu 2018).

In this paper, we sought to assess the wildlife attitudes and preferences of Singapore residents.

Specifically, we asked: 1 . Which kinds of broad animal groups did Singapore residents know, like and were willing to coexist with, and 2. Whether their attitudes towards different kinds of wildlife were influenced by their childhood nature experience, wildlife experience and socioeconomic factors.

\section{Methods}

\subsection{Study site}


Our study site was Singapore, a densely-populated, highly urban and developed island country in Southeast Asia (Singapore Department of Statistics 2019). Wilderness in the form of rubber plantations and secondary forests were widespread in the country from the 1850s to 1960 s (Corlett 1991). From the 1970s, large-scale forest-clearance began for residential and industrial development. The only officiallyprotected forests before independence in 1965 were the water catchment areas in central Singapore (Corlett 1997). Biodiversity losses from forest conversion and habitat fragmentation have been welldocumented (Chan and Davison 2019). Currently, forested areas are concentrated in the central part of Singapore where they act as water catchments, while the urban areas are filled with planted greenery.

\subsection{Questionnaire}

We designed an online questionnaire that covered the exposure, attitudes and willingness to coexist with a series of different wildlife taxa that can be found in Singapore. We recruited 1004 respondents living in Singapore aged 18-69 years using an Internet research company (Macromill, Inc.) in 2016. The gender ratio was even (502 male and female respondents), and $82 \%$ of the respondents spent their childhood (age $\leq 12$ ) in Singapore. The highest education level, ethnicity, and childhood nature experience of each respondent was recorded (Ngo et al. 2019).

In addition, we asked respondents about their knowledge, attitudes and habitat preferences of 26 animals. These animals ranged from common urban ones, such as sparrows, crows, and butterflies, to exclusively forest animals like flying lemurs (Galeopterus variegatus), shrews, and flying squirrels. Wildlife experience was scored on a scale of 1 to 5 with 1 being "do not know", 2 "only know by name", 3 "have watched photo or video", 4 "have watched in the zoo, insectarium etc." and 5 "have watched in the wild". Wildlife likeability was scored on a scale of 1 (dislike) to 5 (like), with 3 as a neutral point. Wildlife habitat preferences, or desirable place for wildlife to live, which we used as a measure of coexistence, was scored on a scale of 1 to 4 with 1 being "nowhere", 2 "forests and parks apart from your house", 3 "green spaces near your home", and 4 "anywhere including your home garden or veranda". Both wildlife likeability and habitat preference scores for each respondent were averaged across the 26 animals.

Childhood nature experience was the average score from two questions - the frequency of green space use and the frequency of participation in nature-related activities in their childhood (age $\leq 12)$. Green spaces included forests, parks, farms/plantations, and rivers/beaches, while nature-related activities included insect-catching, collecting flowers and fruits, bird-watching, tree-climbing, fishing and swimming in rivers/oceans. The two questions had a 5-point scale, ranging from 1 (never; no experience) to 5 (very often; almost everyday), with 3 being sometimes (about once a month). Further details on the questionnaire can be found in Ngo et al. (2019).

\subsection{Data analysis}

We removed six respondents whose answers were 'do not know' for all 26 animals, because their likeability and habitat preference scores were also empty. The six were all male respondents. The Cronbach's alpha for the childhood nature experience questions was 0.91 , that for wildlife experience 
(0.95), likeability (0.95) and habitat preference scores (0.94), which were all higher than the recommended 0.8 reliability (Lance et al. 2006).

We used wildlife likeability and habitat preferences to see how the 26 animals were viewed favorably or unfavorably, and used factor analysis to group animals based on likeability and habitat preference scores. We also used linear regression to examine the relationship between wildlife likeability and habitat preference. We performed multiple linear regression with wildlife likeability and habitat preference as response variables for each animal group, and childhood nature experience, wildlife experience, gender, age, education and ethnicity as predictor variables. We checked the model residuals and confirmed that the error distributions were approximately normal for all the regressions except habitat preference of mammals, but since the results did not differ after transforming the data we used untransformed data for all regressions. Differences in childhood nature experience, wildlife experience, likeability, and habitat preferences between gender (t-test), education levels (ANOVA), ethnicity (ANOVA) and age (linear regression) were plotted and presented in Fig. S1-4.

We used R 4.0.3 (R Core Team, 2020), the psych (v2.0.9; Revelle, 2020) and tidyverse (v1.3.0; Wickham, 2019) packages for analyses and graphics.

\section{Results}

Amongst the 26 animals, small ones that can be found in urban habitats, such as butterfly, dragonfly, and sparrow, had the most direct observations by respondents (Fig. 1). Forest animals such as flying lemur and shrew were the least encountered animals.

Three groups of animals were identified from the likeability and habitat preference scores - favorable animals, mammals, and unfavorable animals (Fig. 2; Table S1). The nine favorable animals included common and small urban animals such as butterflies, dragonflies, and sparrows. This group had the highest likeability and habitat preference scores. The mammal group had 7 of the 8 mammals in the questionnaire (squirrel was in the favorable animal group). Although likeability scores for this group was intermediate, they were all preferred in forests far away from homes (Fig. 2). The unfavorable animal group had 10 animals, with six invertebrates, three herptiles (snake, water monitor, frog) and one bird (crow). Of the six invertebrates, only two were commonly perceived as causing harm to humans (hornet and bee). The moth, beetle, cricket, frog and cicada were on the higher end of both likeability and habitat preference scores within this group. Forest-dependent animals were found in all three groups, although most of the mammals in the questionnaire were forest-dependent.

Childhood nature experience had significant positive effects on both wildlife likeability and habitat preference across all three animal groups, but it was not always the strongest predictor (Table 1). Wildlife experience (knowledge) had strong effects on wildlife likeability, especially for mammals and favorable animals. Wildlife experience was the strongest predictor of wildlife habitat preferences for unfavorable and favorable animals, but was not significant for mammals (Table 1). Gender was the strongest predictor for the likeability of unfavorable animals. Males and those with higher education levels tended 
to have higher likeability and habitat preference scores (Fig. S1, S2). Education level and ethnicity were significant factors in most of the regressions for likeability and habitat preference, and their coefficients were ranked between two to six depending on the animal group. Interestingly the Chinese and Malays had the lowest likeability scores, followed by Indians and other races (Fig. S3). Age had the smallest coefficient in all of the regressions.

Table 1

Linear regression coefficients and $\mathrm{R}^{2}$ for each animal group identified by factor analysis. * $p$-value $<0.05$; ** $\mathrm{p}$-value $<0.01 ; * \star \star \mathrm{p}$-value $<0.001$

\begin{tabular}{|c|c|c|c|c|c|c|c|}
\hline & $\begin{array}{l}\text { Childhood } \\
\text { nature } \\
\text { experience }\end{array}$ & $\begin{array}{l}\text { Wildlife } \\
\text { experience } \\
\text { (knowledge) }\end{array}$ & Gender & Age & Education & Ethnicity & $\mathrm{R}^{2}$ \\
\hline \multicolumn{8}{|l|}{ Likeability } \\
\hline $\begin{array}{l}\text { Unfavorable } \\
\text { animals }\end{array}$ & $0.251^{\star \star \star}$ & $0.117 * \star$ & $-0.323^{\star \star \star}$ & -0.000 & $0.112^{\star \star \star}$ & $0.164^{\star \star \star}$ & 0.180 \\
\hline Mammals & $0.200 * \star \star$ & $0.329 * \star \star$ & 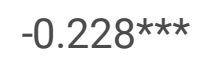 & $-0.011 * \star \star$ & 0.038 & $0.101^{\star \star}$ & 0.204 \\
\hline $\begin{array}{l}\text { Favorable } \\
\text { animals }\end{array}$ & $0.146^{\star \star \star}$ & $0.408^{\star \star *}$ & -0.041 & 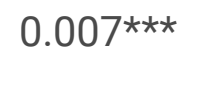 & $0.077 * \star$ & 0.100 & 0.244 \\
\hline All & $0.206^{\star \star \star}$ & $0.267 * \star \star$ & $-0.202^{\star \star \star}$ & 0.000 & $0.083^{* *}$ & $0.130 * \star *$ & 0.251 \\
\hline \multicolumn{8}{|l|}{$\begin{array}{l}\text { Habitat } \\
\text { preference }\end{array}$} \\
\hline $\begin{array}{l}\text { Unfavorable } \\
\text { animals }\end{array}$ & $0.093^{\star * *}$ & $0.156^{\star \star \star}$ & -0.053 & -0.001 & $0.102^{\star \star \star}$ & $0.069 * \star$ & 0.102 \\
\hline Mammals & $0.129 * \star \star$ & 0.032 & $-0.070 *$ & $-0.003^{\star \star}$ & $0.070 * \star \star$ & 0.026 & 0.111 \\
\hline $\begin{array}{l}\text { Favorable } \\
\text { animals }\end{array}$ & $0.065^{\star \star}$ & $0.263^{\star \star \star}$ & 0.065 & $0.004^{*}$ & $0.053^{*}$ & $0.067^{\star \star}$ & 0.127 \\
\hline All & $0.093^{\star * *}$ & $0.151 * \star \star$ & -0.016 & 0.000 & $0.078 * \star \star$ & $0.058 * \star$ & 0.129 \\
\hline
\end{tabular}

\section{Discussion}

Childhood nature experience was found to be low amongst Singapore residents in a previous study, and this was attributed to low levels of nature consciousness when respondents were growing up ( $\mathrm{Ngo}$ et al. 2019). Singapore residents were generally willing to coexist with wildlife that are common in the urban landscape and are small in size, such as butterfly, dragonfly and sparrow. These findings were similar to surveys done in Japan, Malaysia and Norway, where small and common animals had the highest coexistence scores (Bjerke and Østdahl 2004; Hosaka et al. 2017; Mohamad Muslim et al. 2018). However, unfavorable wildlife, and larger mammals, even if well-liked, were preferred away from homes.

The strong effect of childhood nature experience on wildlife attitudes was similar to results from other cities (e.g. Hosaka et al. 2017; Mohamad Muslim et al. 2018; Soga et al. 2016a). We also found that 
wildlife experience played an important role in wildlife likability and habitat preferences, sometimes even more so than childhood nature experience. This shows that having direct experiences with wildlife species, like seeing them with one's own eyes, compared to watching them on a documentary or reading about them, was more effective in fostering better attitudes towards wildlife. However, other studies have shown that childhood nature experience was not always necessary in forming closer connections with nature in adulthood, provided that they have plenty of exposure to nature regularly in adulthood (van den Berg et al. 2016).

Wanting large and undesirable animals away from homes could be a manifestation of the not-in-mybackyard (NIMBY) syndrome. It is a prevalent attitude, which started as a resistance to social and environmental facilities deemed necessary but undesirable near residents of high-value housing estates (Dear 1992). It has rarely been described for wildlife (but see Welbergen and Eby 2016), although NIMBY attitudes have been highlighted in Singapore previously over social facilities (Seow 2017; Yong 2020). In the case of wildlife, fear of zoonotic diseases, fear of injury, noise, and interference with daily life are some of the reasons people may want wildlife far from their homes, but without exterminating them (Ngo et al. 2019). For example, non-biting midge (Polypedilum nubifer and Tanytarsus oscillans) outbreaks have been known to occur in Singapore since the 1970s (Cranston et al. 2013), but their swarming behavior has been considered problematic even though they are harmless to humans (Ang 2019). There has also been numerous cases of macaques and wild boar in Singapore showing aggression to and injuring people in urban settings (e.g. Ang 2020; Yang 2017).

The unfavorable animal group included harmless animals like moths and cicadas, and also animals presumed to cause harm such as bees, hornets and reptiles (snakes, water monitors). This is similar to other studies on attitudes towards these animals (e.g. Almeida et al. 2014; Kellert 1993), and they are likely driven by fear and disgust (Castillo-Huitrón et al. 2020; Polák et al. 2020). The fear of snakes by primates has been attributed to evolution (Isbell 2006) and were considered innate in humans (Menzies and Clarke 1995; Poulton and Menzies 2002). However, social constructs acquired later in life, like myths (Prokop et al. 2009), can also induce fear even if there had been no prior interactions with the wildlife species. A survey done across seven different countries found that although disgust-relevant animals were similar across all cultures, fear ratings differed between countries for fear-irrelevant, fear-relevant, and disgust-relevant animals (Davey et al. 1998), a sign that most of these fears were learnt from cultural settings. Formal education that involves interacting with unfavorable wildlife species in a controlled environment can reduce fears and improve perceptions (Pinheiro et al. 2016).

The strong differences in wildlife likeability between gender was within expectations, especially for the unfavorable animals. Similar to this study, others have shown that females tended to have lower likeability towards wildlife (Kaltenborn et al. 2006; Kellert and Berry 1987), or higher affinity for 'lovable animals' and lower affinity for 'fear-relevant animals' (Schlegel and Rupf 2010). This was despite no significant differences in wildlife experience between males and females. This does not necessarily imply that females were not interested in wildlife conservation, but might reflect greater fear of the dangers that wildlife could bring (Kong et al. 1997; Thornton and Quinn 2009). Singaporean females may see 
themselves more as nurturers in terms of tending to nature and teaching children about nature, instead of having the need or ability to dominate nature (Kong et al. 1997). However, it may be useful to note we found no significant effect of gender on overall habitat preferences, reflecting similar preferences between males and females.

In our study, we found that higher formal education level correlated with higher likeability and tolerance of wildlife. This concurs with findings from Kaltenborn et al. (2006) and Røskaft et al. (2003), while Thornton and Quinn (2009) found no such relation. Randler et al. (2007) also found that education level and age were significant predictors of animal knowledge. A majority (57.2\%) of respondents had a degree, while $10.8 \%$ had a postgraduate degree. A survey on Singapore undergraduates found that biology majors did not fare much better than non-biology majors when asked about their environmental knowledge and understanding of ecosystems (Tan 2015). Future studies could include a question on subject of specialization for respondents with degrees to examine if the subject of study had any influence on wildlife attitudes.

Ethnicity had a significant effect on wildlife likeability and habitat preference, similar to a Malaysian study (Mohamad Muslim et al. 2018). However, although Singapore and Malaysia share similar ethnicities, Malaysia has a Malay majority, while Singapore has an ethnic Chinese majority. Consequently, $84 \%$ of respondents from this study were Chinese, which was higher than the national average of $74.3 \%$ (Singapore Department of Statistics 2020). Contrary to findings from Mohamad Muslim et al. (2018), the Malay respondents in our study had the lowest mean scores for childhood nature experience, wildlife experience and habitat preferences, compared to other ethnicities (Fig. S3). It is unclear if this could be due to the small proportion of Malays (5.2\%) who answered the questionnaire, compared to the national proportion of $13.5 \%$ (Singapore Department of Statistics 2020).

Age had little effect on wildlife likeability and habitat preferences in general (Table 1; Fig. S4). This is contrary to findings from Bjerke and Østdahl (2004), Hosaka et al. 2017, and Mohamad Muslim et al. (2018), but were similar to Kaltenborn et al. (2006). In a previous study with the same survey respondents, likeability and tolerance was found to decrease with age, but that was only for three species of problemcausing wildlife ( $\mathrm{Ngo}$ et al. 2019). The weak effect of age may be because Singapore had become highly urbanized by the 1970s (MND 2019), where people in their 40s and below would have been born, so these generations may have had little exposure to nature when growing up. Prior to this, most of Singapore's population were concentrated in the then built-up and crowded areas (Neville 1969; Ngo et al. 2019), and people in their 50s and above may have had grown up with little exposure to nature even though there were more forests before the 1970s.

Although most respondents had first-hand experience with common urban animals (seen the animal physically), forest-dependent animals, mostly mammals, such as flying lemurs and shrews, were unknown or known only by name by over $25 \%$ of the respondents. Low levels of wildlife knowledge are not unique to this study (e.g. Bebbington 2005; Miller and McGee 2000). Studies have shown that wildlife knowledge and interest in children can be enhanced by regular exposure to them, coupled with 
opportunities to study them in more detail (Lindemann-Matthies 2005). Even adults with regular exposure to nature in cities can have increased commitment to biodiversity conservation (Prévot et al. 2018). Elementary science education in Singapore in the 1990s and before (when most of the survey respondents would have been studying) were fact-based (Lee 2018). Despite this, there was very little to connect textbook knowledge with the environment. Teaching facts alone does not necessarily result in more positive attitudes towards wildlife (Prokop et al. 2009). With the current emphasis on evidencebased reasoning and knowledge application in science education (Lee 2018), there is even less motivation for students to learn about species around them if they do not appear in school examinations. School field trips to nature reserves also usually involve large groups (pers. obs.), which are not conducive to watching wildlife.

The preferred landscape in Singapore is manicured landscapes like parks and gardens (Drillet et al. 2020; Khew et al. 2014), which harbor lower biodiversity than natural habitats such as forests (Chong et al. 2014). Most of the mammals and some unfavorable animals surveyed are found in forests. The preference for manicured landscapes was despite a general tendency towards nature conservation (Khew et al. 2014). This could lead to a positive feedback cycle where children are mostly exposed to manicured landscapes, reinforcing their preference in adulthood, and paving the way for more manicured landscapes in the future and reducing habitats for more endangered species. However, the recent slogan change for Singapore to be a 'City in Nature' from the previous 'City in a Garden' requires its citizens to learn to coexist with wildlife around them (Lee 2017), including the unfavorable animals. Besides policy, effective biodiversity conservation requires widespread support from citizens living in biodiversity hotspots to also be supportive of conservation measures.

\section{Declarations}

Acknowledgements

This study was supported by the Advanced Research Program of the Asian Human Research Fund of the Tokyo Metropolitan Government. Dr. Koun Sugimoto helped with the questionnaire survey.

\section{Affiliations}

Department of Tourism Science, Graduate School of Urban Environmental Sciences, Tokyo Metropolitan University, 1-1 Minamiosawa, Hachioji, Tokyo, 192-0397, Japan

Kang Min Ngo, Tetsuro Hosaka, Shinya Numata

Present addresses:

Asian School of the Environment, Nanyang Technological University, 50 Nanyang Avenue, 639798, Singapore

Kang Min Ngo 
Graduate School for International Development and Cooperation, Hiroshima University, 1-5-1, Kagamiyama, Higashihiroshima, 739-852, Japan Tetsuro Hosaka

\section{Contributions}

All authors contributed to this manuscript. Data collection was done by Tetsuro Hosaka and Shinya Numata. Analysis and writing were performed by Kang Min Ngo, with assistance by Tetsuro Hosaka. All authors commented on previous versions of the manuscript. All authors read and approved the final manuscript.

The authors have no conflicts of interest to declare that are relevant to the content of this article.

\section{References}

1. Almeida A, Vasconcelos C, Strecht-Ribeiro O (2014) Attitudes toward animals: A study of Portuguese children. Anthrozoos 27:173-190. https://doi.org/10.2752/175303714X13903827487403

2. Ang HM (2019) Pandan Reservoir midge infestation: ' You can say that we've given up'. Channel News Asia. https://www.channelnewsasia.com/news/singapore/pandan-reservoir-midge-infestationyou-can-say-that-we-ve-given-11879188. Accessed 10 October 2020

3. Ang Q (2020) Woman attacked by wild boar while exercising in Sungei Api Api Park. The Straits Times. https://www.straitstimes.com/singapore/woman-attacked-by-wild-boar-while-exercising-insungei-api-api-park. Accessed 31 December 2020

4. Anguelovski I, Argüelles L, Baró F, et al (2018) Green Trajectories: Municipal policy trends and strategies for greening in Europe, Canada and United States (1990-2016). BCNUEJ, Barcelona

5. Aronson MFJ, Lepczyk CA, Evans KL, et al (2017) Biodiversity in the city: key challenges for urban green space management. Front Ecol Environ 15:189-196. https://doi.org/10.1002/fee.1480

6. Bebbington A (2005) The ability of A-level students to name plants. J Biol Educ 39:63-67. https://doi.org/10.1080/00219266.2005.9655963

7. Bjerke T, Østdahl T (2004) Animal-related attitudes and activities in an urban population. Anthrozoos 17:109-129. https://doi.org/10.2752/089279304786991783

8. Butchart SHM, Walpole M, Collen B, et al (2010) Global biodiversity: indicators of recent declines. Science (80- ) 328:1164-1168. https://doi.org/10.1126/science.1187512

9. Cardinale BJ, Duffy JE, Gonzalez A, et al (2012) Biodiversity loss and its impact on humanity. Nature 486:59-67. https://doi.org/10.1038/nature11148

10. Castillo-Huitrón NM, Naranjo EJ, Santos-Fita D, Estrada-Lugo E (2020) The importance of human emotions for wildlife conservation. Front Psychol 11:1-11.

https://doi.org/10.3389/fpsyg.2020.01277

11. Chan L, Davison GWH (2019) Introduction to the Comprehensive Biodiversity Survey of Bukit Timah Nature Reserve, Singapore, 2014-2018. Gard Bull Singapore 71:3-17.

https://doi.org/10.26492/gbs71(suppl.1).2019-02 
12. Chapin FS, Zavaleta ES, Eviner VT, et al (2000) Consequences of changing biodiversity. Nature 405:234-42. https://doi.org/10.1038/35012241

13. Chawla L, Derr V (2012) The development of conservation behaviors in childhood and youth. Oxford Handb Environ Conserv Psychol 527-555. https://doi.org/10.1093/oxfordhb/9780199733026.013.0028

14. Chong KY, Teo S, Kurukulasuriya B, et al (2014) Not all green is as good: Different effects of the natural and cultivated components of urban vegetation on bird and butterfly diversity. Biol Conserv 171:299-309. https://doi.org/10.1016/j.biocon.2014.01.037

15. Corlett RT (1997) The vegetation in the nature reserves of Singapore. Gard Bull Singapore 49:147159

16. Corlett RT (1991) Plant succession on degraded land in Singapore. J Trop For Sci 4:151-161

17. Cranston PS, Ang YC, Heyzer A, et al (2013) The nuisance midges (Diptera: Chironomidae) of Singapore's Pandan and Bedok reservoirs. Raffles Bull Zool 61:779-793

18. Crespin SJ, Simonetti JA (2019) Reconciling farming and wild nature: Integrating human-wildlife coexistence into the land-sharing and land-sparing framework. Ambio 48:131-138. https://doi.org/10.1007/s13280-018-1059-2

19. Davey GCL, McDonald AS, Hirisave U, et al (1998) A cross-cultural study of animal fears. Behav Res Ther 36:735-750. https://doi.org/10.1016/S0005-7967(98)00059-X

20. Dear M (1992) Understanding and overcoming the NIMBY syndrome. J Am Plan Assoc 58:288-300. https://doi.org/10.1080/01944369208975808

21. Drillet Z, Fung TK, Leong RAT, et al (2020) Urban vegetation types are not perceived equally in providing ecosystem services and disservices. Sustainability 12:2076.

https://doi.org/10.3390/su12052076

22. Feng $Z$ (2013) Monkey complaints up, so culling rises too. The Straits Times. https://www.straitstimes.com/singapore/monkey-complaints-up-so-culling-rises-too. Accessed 4 October 2018

23. Frank B (2016) Human-wildlife conflicts and the need to include tolerance and coexistence: an introductory comment. Soc Nat Resour 29:738-743.

https://doi.org/10.1080/08941920.2015.1103388

24. Goh T, Toh TW (2018) AVA received 150 cases of wild-boar-related feedback from January to July 2018, more than entire year 2016. The Straits Times. https://www.straitstimes.com/singapore/avareceived-150-cases-of-wild-boar-related-feedback-from-january-to-july-2018-more-than. Accessed 16 October 2020

25. Hicks R (2020) Nature is thriving in locked-down Singapore - is it time to rethink the city in a garden? Eco-Business. https://www.eco-business.com/news/in-pictures-nature-is-thriving-in-locked-downsingapore-is-it-time-to-rethink-the-city-in-a-garden/. Accessed 31 December 2020

26. Hosaka T, Sugimoto K, Numata S (2017) Childhood experience of nature influences the willingness to coexist with biodiversity in cities. Palgrave Commun 3:17071. 
https://doi.org/10.1057/palcomms.2017.71

27. Hsu SJ (2009) Significant life experiences affect environmental action: a confirmation study in eastern Taiwan. Environ Educ Res 15:497-517. https://doi.org/10.1080/13504620903076973

28. Isbell LA (2006) Snakes as agents of evolutionary change in primate brains. J Hum Evol 51:1-35. https://doi.org/10.1016/j.jhevol.2005.12.012

29. Jamal NH (2020) Residents turn wildlife observers during circuit breaker period. The Straits Times. https://www.straitstimes.com/singapore/residents-turn-wildlife-observers-during-circuitbreaker-period. Accessed 31 December 2020

30. Jim CY, Chen SS (2003) Comprehensive greenspace planning based on landscape ecology principles in compact Nanjing city, China. Landsc Urban Plan 65:95-116. https://doi.org/10.1016/S01692046(02)00244-X

31. Kaltenborn BP, Bjerke T, Nyahongo JW, Williams DR (2006) Animal preferences and acceptability of wildlife management actions around Serengeti National Park, Tanzania. Biodivers Conserv 15:46334649. https://doi.org/10.1007/s10531-005-6196-9

32. Kellert SR (1993) Values and perceptions of invertebrates. Conserv Biol 7:845-855

33. Kellert SR, Berry JK (1987) Attitudes, knowledge, and behaviors toward wildlife as affected by gender. Wild Soc Bull 15:363-371

34. Khew JYT, Yokohari M, Tanaka T (2014) Public perceptions of nature and landscape preference in Singapore. Hum Ecol 42:979-988. https://doi.org/10.1007/s10745-014-9709-x

35. Kong LLL, Yuen B, Briffett C, Sodhi NS (1997) Nature and nurture, danger and delight: urban women's experiences of the natural world. Landsc Res 22:245-266.

https://doi.org/10.1080/01426399708706514

36. Kowarik I (2011) Novel urban ecosystems, biodiversity, and conservation. Environ Pollut 159:19741983. https://doi.org/10.1016/j.envpol.2011.02.022

37. Lance CE, Butts MM, Michels LC (2006) The sources of four commonly reported cutoff criteria: What did they really say? Organ Res Methods 9:202-220. https://doi.org/10.1177/1094428105284919

38. Lee D (2017) Speech by 2M Desmond Lee at Conversations with Dr Goodall. https://www.mnd.gov.sg/newsroom/speeches/view/speech-by-2m-desmond-lee-atconversations-with-dr-goodall. Accessed 2 November 2020

39. Lee Y-J (2018) Primary science education in Singapore: a critical comparison of systems and strategies. In: Lee Y-J, Tan J (eds) Primary Science Education in East Asia. Springer, pp 157-176

40. Li D, Chen J (2015) Significant life experiences on the formation of environmental action among Chinese college students. Environ Educ Res 21:612-630.

https://doi.org/10.1080/13504622.2014.927830

41. Li F, Wang R, Paulussen J, Liu X (2005) Comprehensive concept planning of urban greening based on ecological principles: A case study in Beijing, China. Landsc Urban Plan 72:325-336. https://doi.org/10.1016/j.landurbplan.2004.04.002 
42. Lindemann-Matthies $P$ (2005) "Loveable" mammals and "lifeless" plants: How children's interest in common local organisms can be enhanced through observation of nature. Int J Sci Educ 27:655677. https://doi.org/10.1080/09500690500038116

43. Liu WT (2018) Positioning native wildlife in Asian cities: Human-wildlife interactions in Singapore. Dissertation, National University of Singapore

44. Menzies RG, Clarke JC (1995) The etiology of phobias: a nonassociative account. Clin Psychol Rev 15:23-48. https://doi.org/10.1016/0272-7358(94)00039-5

45. Miller KK, McGee TK (2000) Sex differences in values and knowledge of wildlife in victoria, Australia. Hum Dimens Wildl 5:54-68. https://doi.org/10.1080/10871200009359179

46. MND (2019) Groundbreaking: 60 years of National Development in Singapore. https://www.clc.gov.sg/docs/default-source/books/groundbreaking-60-years-of-nationaldevelopment-in-singapore.pdf. Accessed 16 December 2020

47. Mohamad Muslim HF, Hosaka T, Numata S, Yahya NA (2017) Nature-Related Experience during Childhood in Urban and Rural Areas: The Case of Peninsular Malaysians. Urban Stud Res 2017:1-9. https://doi.org/10.1155/2017/7349219

48. Mohamad Muslim HF, Tetsuro H, Shinya N, Yahya NA (2018) Nature experience promotes preference for and willingness to coexist with wild animals among urban and suburban residents in Malaysia. Ecol Process 7:. https://doi.org/10.1186/s13717-018-0127-7

49. Neville W (1969) The distribution of population in the post-war period. In: Ooi J-B, Chiang HD (eds) Modern Singapore. University of Singapore, Singapore, pp 52-68

50. Ngo KM, Hosaka T, Numata S (2019) The influence of childhood nature experience on attitudes and tolerance towards problem-causing animals in Singapore. Urban For Urban Green 41:150-157. https://doi.org/10.1016/j.ufug.2019.04.003

51. Pinheiro LT, Rodrigues JFM, Borges-Nojosa DM (2016) Formal education, previous interaction and perception influence the attitudes of people toward the conservation of snakes in a large urban center of northeastern Brazil. J Ethnobiol Ethnomed 12:1-8. https://doi.org/10.1186/s13002-016-0096-9

52. Polák J, Rádlová S, Janovcová M, et al (2020) Scary and nasty beasts: Self-reported fear and disgust of common phobic animals. Br J Psychol 111:297-321. https://doi.org/10.1111/bjop.12409

53. Poulton R, Menzies RG (2002) Non-associative fear acquisition: A review of the evidence from retrospective and longitudinal research. Behav Res Ther 40:127-149. https://doi.org/10.1016/S0005-7967(01)00045-6

54. Prévot AC, Cheval H, Raymond R, Cosquer A (2018) Routine experiences of nature in cities can increase personal commitment toward biodiversity conservation. Biol Conserv 226:1-8. https://doi.org/10.1016/j.biocon.2018.07.008

55. Prokop P, Özel M, Uşak M (2009) Cross-cultural comparison of student attitudes toward snakes. Soc Anim 17:224-240. https://doi.org/10.1163/156853009X445398

56. Randler C, Höllwarth A, Schaal S (2007) Urban park visitors and their knowledge of animal species. Anthrozoos 20:65-74. https://doi.org/10.2752/089279307780216696 
57. Reibelt LM, Richter T, Rendigs A, Mantilla-Contreras J (2017) Malagasy conservationists and environmental educators: Life paths into conservation. Sustainability 9:1-15. https://doi.org/10.3390/su9020227

58. Revelle W (2020) R package, psych: Procedures for Personality and Psychological Research

59. Røskaft E, Bjerke T, Kaltenborn B, et al (2003) Patterns of self-reported fear towards large carnivores among the Norwegian public. Evol Hum Behav 24:184-198. https://doi.org/10.1016/S10905138(03)00011-4

60. Schlegel J, Rupf R (2010) Attitudes towards potential animal flagship species in nature conservation: A survey among students of different educational institutions. J Nat Conserv 18:278-290. https://doi.org/10.1016/j.jnc.2009.12.002

61. Seow BY (2017) A little less Nimby. The Straits Times. http://www.straitstimes.com/singapore/housing/a-little-less-nimby. Accessed 10 October 2020

62. Sha JCM, Gumert MD, Lee BPYH, et al (2009) Macaque-human interactions and the societal perceptions of macaques in Singapore. Am J Primatol 71:825-839. https://doi.org/10.1002/ajp.20710

63. Singapore Department of Statistics (2020) Population Trends, 2020. https://www.singstat.gov.sg/-/media/files/publications/population/population2020.pdf. Accessed 4 October 2020

64. Singapore Department of Statistics (2019) Yearbook of Statistics Singapore. https://www.singstat.gov.sg/-/media/files/publications/reference/yearbook_2019/yos2019.pdf. Accessed 9 August 2020

65. Soga M, Gaston KJ, Koyanagi TF, et al (2016) Urban residents' perceptions of neighbourhood nature: Does the extinction of experience matter? Biol Conserv 203:143-150. https://doi.org/10.1016/j.biocon.2016.09.020

66. Soga M, Gaston KJ, Yamaura Y, et al (2016) Both direct and vicarious experiences of nature affect children's willingness to conserve biodiversity. Int J Environ Res Public Health 13:529. https://doi.org/10.3390/ijerph13060529

67. Strohbach MW, Lerman SB, Warren PS (2013) Are small greening areas enhancing bird diversity? Insights from community-driven greening projects in Boston. Landsc Urban Plan 114:69-79. https://doi.org/10.1016/j.landurbplan.2013.02.007

68. Tan A (2019) Panic as family finds $3 \mathrm{~m}$-long python in toilet, then struggles to find agency to help remove snake. The Straits Times. https://www.straitstimes.com/singapore/panic-as-family-finds-3mlong-python-in-toilet-then-struggles-to-find-agency-to-help. Accessed 16 November 2020

69. Tan YK (2015) Boon or Bane?: An Investigation into Altitude and Attitude of Youths in Singapore on Nature Conservation. Dissertation, National Institute of Education

70. Thornton C, Quinn MS (2009) Coexisting with cougars: public perceptions, attitudes, and awareness of cougars on the urban-rural fringe of Calgary, Alberta, Canada. Human-Wildlife Conflicts 3:282-295 
71. Trisos $\mathrm{CH}$, Merow C, Pigot AL (2020) The projected timing of abrupt ecological disruption from climate change. Nature 580:1-6. https://doi.org/10.1038/s41586-020-2189-9

72. Van den Berg M, Van Poppel M, Van Kamp I, et al (2016) Visiting green space is associated with mental health and vitality: A cross-sectional study in four european cities. Heal Place 38:8-15. https://doi.org/10.1016/j.healthplace.2016.01.003

73. Welbergen J, Eby $P$ (2016) Not in my backyard? How to live alongside flying-foxes in urban Australia. Conversat. https://theconversation.com/not-in-my-backyard-how-to-live-alongside-flying-foxes-inurban-australia-59893. Accessed 8 October 2020

74. Wickham H, Averick M, Bryan J, et al (2019) Welcome to the Tidyverse. J Open Source Softw 4:1686. https://doi.org/10.21105/joss.01686

75. Yang C (2017) Segar Rd residents worry over monkey attacks. The Straits Times. https://www.straitstimes.com/singapore/segar-rd-residents-worry-over-monkey-attacks. Accessed 31 December 2020

76. Yeo J-H, Neo H (2010) Monkey business: human-animal conflicts in urban Singapore. Soc Cult Geogr 11:681-699. https://doi.org/10.1080/14649365.2010.508565

77. Yong N (2020) Government asks Singaporeans to reject NIMBY mindset as it overhauls foreign worker housing. Yahoo News Singapore. https://sg.news.yahoo.com/government-askssingaporeans-to-reject-...by-mindset-as-it-overhauls-foreign-worker-housing-105427958.html. Accessed 10 October 2020

78. Zhang W, Goodale E, Chen J (2014) How contact with nature affects children's biophilia, biophobia and conservation attitude in China. Biol Conserv 177:109-116. https://doi.org/10.1016/j.biocon.2014.06.011

\section{Figures}




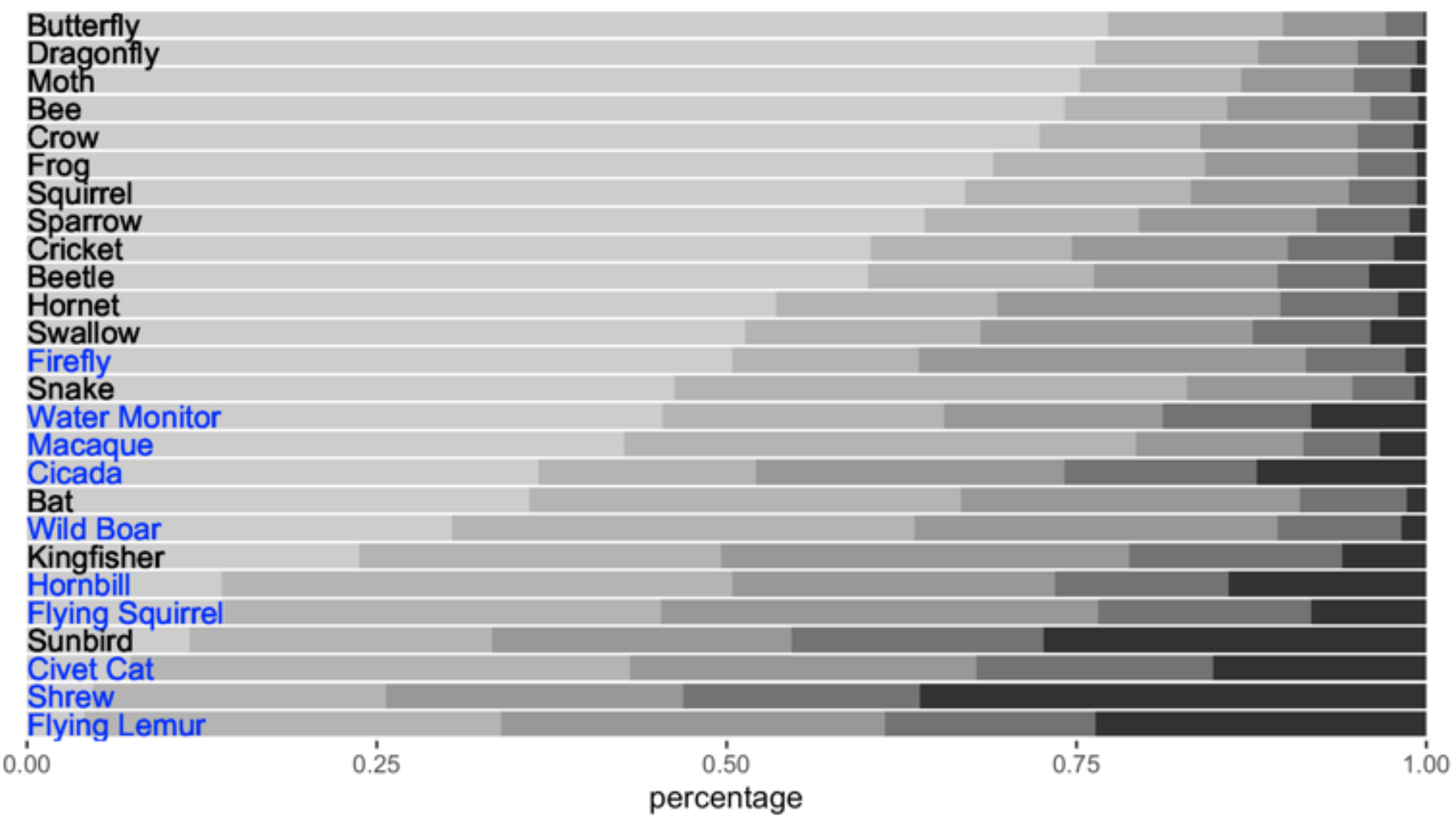

do not know

only know by name

have seen picture or video

have watched in the zoo, insectarium etc.

have watched in the wild

\section{Figure 1}

Respondents' knowledge / familiarity (wildlife experience) of each animal. Animals in blue font are forestdependent, while animals in black font include both urban or forest species. 


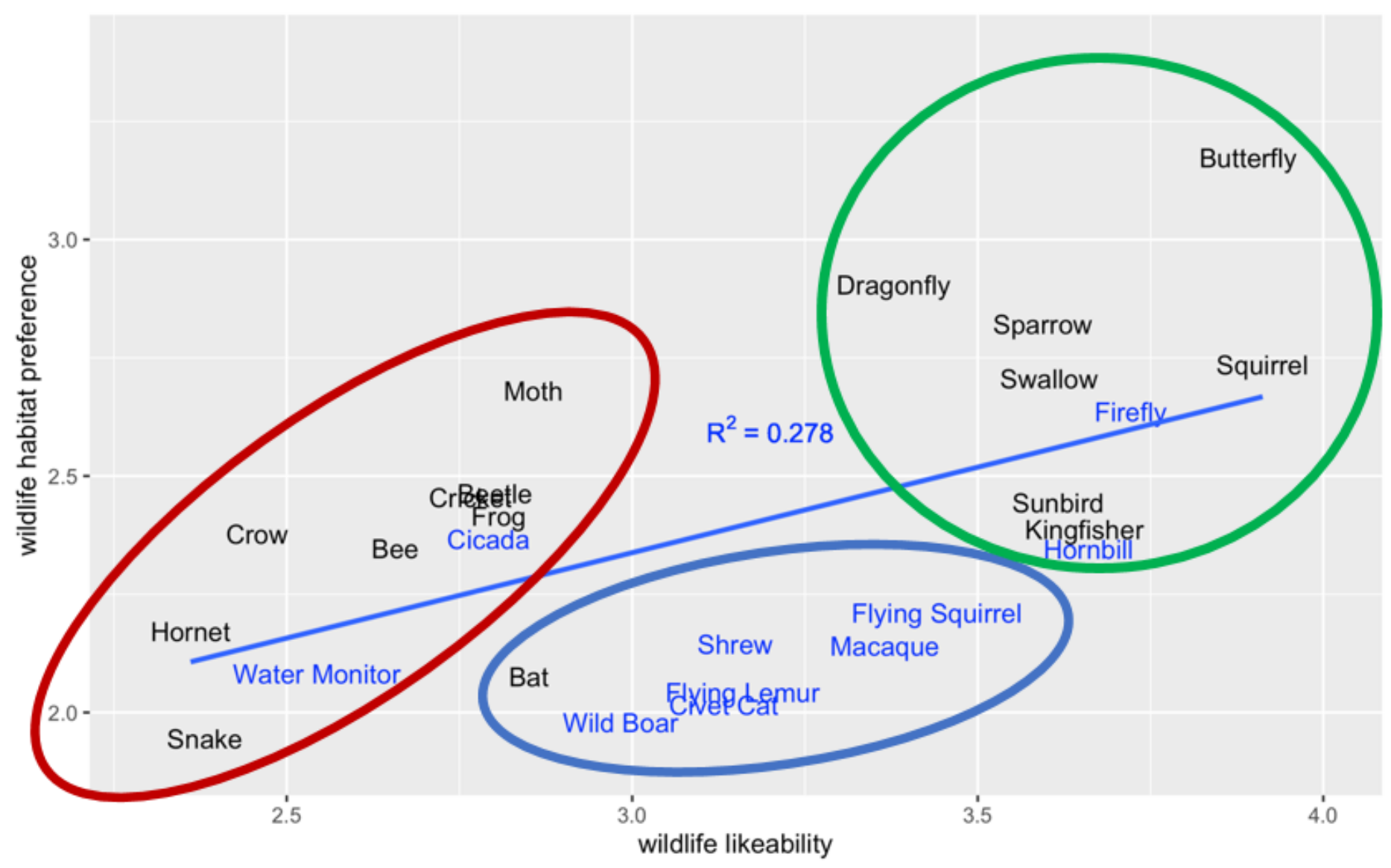

\section{Figure 2}

Wildlife likeability and habitat preference scores of the 26 animals. Circles represent the three main groups of animals identified by factor analysis: unfavorable animals (red ellipse), mammals (blue ellipse), and favorable animals (green ellipse). The blue line represents the best fit model for the linear regression between wildlife likeability and habitat preference $(p=0.003)$. Animals in blue font are forest-dependent, while animals in black font include both urban or forest species.

\section{Supplementary Files}

This is a list of supplementary files associated with this preprint. Click to download.

- SI1.docx 